\title{
Author Correction: Suicide among cancer patients
}

Nicholas G. Zaorsky (1), Ying Zhang, Leonard Tuanquin, Shirley M. Bluethmann, Henry S. Park \&

Vernon M. Chinchilli

Correction to: Nature Communications https://doi.org/10.1038/s41467-018-08170-1, published online 14 January 2019

In the original version of this Article the SEER database was described in Supplementary Note 1. This section has now been updated to include additional information, which was missing from the original file, and describes the registry differences, calculation of standardised mortality rates and latency exclusion periods in standardized mortality ratios and is entitled 'Intricacies of Surveillance, Epidemiology, and End Results (SEER) Databases'.

Published online: 31 January 2020

(c) Open Access This article is licensed under a Creative Commons Attribution 4.0 International License, which permits use, sharing, adaptation, distribution and reproduction in any medium or format, as long as you give appropriate credit to the original author(s) and the source, provide a link to the Creative Commons license, and indicate if changes were made. The images or other third party material in this article are included in the article's Creative Commons license, unless indicated otherwise in a credit line to the material. If material is not included in the article's Creative Commons license and your intended use is not permitted by statutory regulation or exceeds the permitted use, you will need to obtain permission directly from the copyright holder. To view a copy of this license, visit http://creativecommons.org/licenses/by/4.0/.

(c) The Author(s) 2020 